\title{
The June uprising in Turkey
}

\begin{abstract}
The June uprising was an unexpected explosion of the already-accumulated reaction and anger of millions of Turkish citizens that has opened a new chapter in Turkish political history by actualising the most massive, determined and militant mobilisation against the oppressive measures of the government. The aim of the AKP government, which is becoming increasingly authoritarian, to change the basics of the system, together with the weakness of the formal opposition, created the conditions which were suitable for the uprising. This article aims to analyse the history of the events in Gezi Park, and the political, economic and social conditions which led up to it, as well as to provide some early assessment of the significance of the uprising for the future of Turkey and its political structures. Ultimately, this was an uprising against the Power, but it did not aim to overthrow it. Nevertheless, the June uprising has not yet ended and should be analysed well by political scientists aiming to read the future of Turkish politics.
\end{abstract}

Keywords: June uprising in Turkey, Gezi Park, AKP, Erdoğan, demonstrations, civil society, trade unions, neo-liberalism, economic crisis, chapulling, working classes, white-collar workers, women, young people, ethnic and religious minorities

\section{Introduction}

Everything started with a cloud of spray. Then an unexpected explosion of the already accumulated reaction and anger of millions of Turkish citizens came to the light, opening a new chapter in Turkish political history by actualising the most massive, determined and militant mobilisation against the oppressive measures of the government.

Taksim is the central square in Istanbul. This square is not only a place of attraction for tourists but also for all kinds of political movements seeking to gather and express their demands. It is important to note that Taksim Square is a symbolic place for the labour movement in Turkey, in which the May Day massacre occurred in 1977. The last ten years have witnessed the insistence of the labour movement on celebrating May Day in Taksim Square (it has been forbidden since 1977): in some of these, the government has banned the celebration in the Square and police forces have used violence to stop workers trying to reach the Square; in other years, the government has accepted union demands and has allowed demonstrations that have seen hundreds of thousands of people pouring into the Square, making the Istanbul May Day the second most mass May Day on Earth after the one in Havana, Cuba.

Taksim Square owns this historical symbolic importance; however, the June uprising did not occur as a consequence of this historical legacy. Now, the place of at- 
traction was one part of Taksim Square, Gezi Park: the only green area and public park in the central square of Istanbul.

Istanbul is the biggest metropolitan city in Turkey and it has changed very fast in the last fifteen years. This is due to the construction of skyscrapers and shopping malls in all parts of the city, aiming at the exploitation of every piece of land for commercial activities. It is also a way of capital accumulation for rent-seeking business groups which have been encouraged by a government aiming to run the economy via the continuous receipt of short-term foreign debt (Sönmez, 23 June 2013).

Istanbul owns tens of shopping malls, most of which are facing economic difficulties. However, the government planned to destroy Gezi Park and build a shopping mall constructed in the style of the 19th century Ottoman military barracks, Topçu Klşlast. This had been destroyed in the Early Republican Period due to the barracks having the symbolic importance of being the headquarters of the reactionary forces that had rebelled against the Second Constitutional Monarchy in 1909. Therefore, it was not just because of the destruction of the only green area-public park on Taksim Square that was the source of the uprising; this piece of history embodies an ideological-symbolic confrontation between secularists and Islamists.

\section{The brief history of the uprising}

A group of environmentalists, together with some left-wing groups and some members of parliament, protested at the government's decision on the destruction of Gezi Park by pitching up tents in the Park and organising a pacifist and peaceful protest to stop the bulldozers and the Caterpillars. On the early morning of $31 \mathrm{May}$, the police broke up this protest by using an excessive amount of tear gas, beating these few hundred environmentalists and burning their tents. People were able to learn of this violence via media broadcasting: police pouring pepper spray over the face of a young lady wearing a red dress, which later turned out to be one of the symbols of the resistance - the Woman in the Red Dress; kicking another young man who was trying to run away; arresting young people who were embracing trees to protect them; and burning the tents of the protesters.

\section{Istanbul resistance}

On the evening of 31 May, thousands of people gathered in Taksim Square to protest at the police violence against peaceful demonstrators who had been attacked while they were sleeping in their tents. However, instead of a government apology, once again the police attacked people in Taksim. The protestors decided to resist, but they did not have anything with which to protect themselves. The police were using thousands of capsules of pepper spray and firing plastic bullets over them. People left the streets under the pepper spray, but were regrouping in the side street, refusing to leave Taksim. In order to protect themselves from the plastic bullets and the water cannons, people began to build barricades and waited behind them.

At other times, after a few hours of resistance and a few small clashes, protestors usually left the area and police could 'clean' the Square. However, on 31 May, this did 
not occur; protestors did not leave the zone; the entire Square was surrounded with protestors and continuous police violence could not dispatch the masses.

The clashes and the barricades spread outwards to nearby districts, such as Beşiktaş, Şişli and Kurtuluş, and, despite the late night and early morning, the number of protestors was increased by the participation of people living in these districts, angered at the police violence and the arrogance of the government.

Via social media, the resistance was spread to large masses of people and, in different parts of Istanbul, people started to gather in the centre of their districts. ${ }^{1}$ On the Asian side, in Kadıköy, Maltepe and Kartal; on the European side, in Bakırköy and Avc1lar: thousands of people began to gather after $11 \mathrm{pm}$. The author of this article was at Kadıköy at $11.30 \mathrm{pm}$, where there were a few hundred people in the centre and, after a short while, after the demonstration began, thousands of people poured on to the streets to protest against the government. Until $2 \mathrm{am}$, people were gathering together into a larger group which could not be counted easily but which may be defined as tens of thousands, chanting slogans such as 'government resign', 'end to fascism' and 'shoulder to shoulder against fascism', and sharing news from social media with each other that clashes and resistance were continuing in Taksim. Such news motivated people but Taksim is on the European side and there were no ferry or bus services at that time of night, so people decided to walk to Taksim, some $18 \mathrm{~km}$ from Kadıköy.

1 There should be a special focus on the role of social media in the movement. According to research carried out by the Social Media and Political Participation Lab in New York University, between 31 May and 9 June, more than 22 million tweets were shared among the hashtags on the uprising. The research stated that:

'Since $4 \mathrm{pm}$ local time yesterday, (31 May) at least 2 million tweets mentioning hashtags related to the protest, such as \#direngezipark1 (950 000 tweets), \#occupygezi (170 000 tweets) or \#geziparki (50 000 tweets) have been sent. As we show in the plot below, the activity on Twitter was constant throughout the day. Even after midnight local time last night more than 3000 tweets about the protest were published every minute. (...)

'What is unique about this particular case is how Twitter is being used to spread information about the demonstrations on the ground. Unlike some other recent uprisings, around $90 \%$ of all geolocated tweets are coming from within Turkey, and $50 \%$ from within Istanbul. In comparison, Starbird (2012) estimated that only $30 \%$ of those tweeting during the Egyptian revolution were actually in the country. Additionally, approximately $88 \%$ of the tweets are in Turkish, which suggests the audience of the tweets is other Turkish citizens and not so much the international community. These numbers are in spite of the fact that there are reports that the $3 \mathrm{G}$ network is down in much of the area that is affected. Some local shops have removed the security from their WiFi networks to allow internet access, but almost certainly the reduced signal will have impacted the tweeting behavior of those on the ground. (...)

'[On 9 June] social networking sites, such as Twitter, Facebook or Tumblr, appear to be playing a prominent role in the coordination of the still ongoing protests in Turkey. There is abundant evidence suggesting that social media have been pivotal in the spread of information, especially in the absence of coverage by traditional media; to recruit and mobilize protesters; to coordinate the movement without the infrastructure of formal organizations; and to draw the attention and support of the international community. That social media was at the heart of these protests was defiantly acknowledged by the Turkish Prime Minister himself, when he described them as "the worst menace to society". There are also reports that 25 people were arrested because of their use of Twitter to spread information about the protest.' (SMAPP NYU, June 2013). 
On the way, people living around the motorway woke up as a result of the slogans; some participated in the march while others turned their lights on and off to show their support. After walking almost four hours, thousands of people from the Asian side crossed the Bosporus Bridge and reached Beşiktaş, the nearest district to Taksim in which protestors were continuing to resist the police until the morning, thus joining the protests.

With the resistance continuing all night, people kept each other informed via social media, sharing photos and necessary information as where the police were located (so they would not go there), what to do when one has inhaled pepper spray, where to hide, where the nearest doctor lived, etc. Progressive doctors and lawyers were distributing their mobile numbers and addresses via social media and small medical clinics were formed in the houses and offices of some parties and organisations. Photos and videos showed protestors using a Caterpillar and driving over police lines; lorries stopping police vehicles and saving protestors; old ladies distributing lemons and water to protestors who were affected by pepper spray; interesting and, mostly, funny graffiti; and snapshots of police violence: all these motivated people to join in the resistance. The result of the use of social networks was that the number of people participating in the protests increased.

On 1 June, CHP (the Republican Peoples' Party), the social democratic main opposition party, was due to hold a long-planned public meeting in Kadıköy. However, under intense pressure, CHP cancelled the meeting and called everyone to walk across to Taksim Square and to liberate it and Gezi Park. Following the call of this main opposition party, tens of thousands of people who had come to Kadıköy for the meeting poured on to public ferries to pass through Beşiktaş. The ferries, filled similarly to Indian trains, crossed the Bosporus and these people joined the resistance. At $4 \mathrm{pm}$ on 1 June, after more than 24 hours of non-stop resistance, hundreds of thousands of people had surrounded Taksim Square and the police had to withdraw. Over 500000 people filled the Square, re-conquered Gezi Park, hugged its trees once again and celebrated their victory.

People were successful in saving Gezi Park and they were able freely to demonstrate in Taksim Square, but no party or organisation was leading the movement. People from various political currents, from left and right, who opposed the authoritarian rule of the Erdoğan government came together in the Square. Young people again pitched their tents in Gezi Park and the placards of various political organisations were displayed. Taksim Solidarity Platform, composed of over 100 professional organisations, parties and NGOs, which had been established to preserve Gezi Park at the beginning of the year, became the central organisation and network of the movement and acted as its spokesperson in the declaration of common demands. Taksim Square, together with Istiklal Street and Gezi Park, continued to be occupied by the people. Despite the existence of hundreds of thousands of people and the participation of various political and ideological groups, people were nevertheless sensitive to each other in the preservation of the jointly-formed de facto peaceful occupation of the Square. Forums were formed and, via social media platforms, people were able to debate particular issues. 
Taksim Solidarity Platform and its spokesperson Dr. Arzu Çerkezoğlu, the General Secretary of DISK (the Confederation of Progressive Trade Unions of Turkey), released to the press on 2 June that the Platform had five demands:

- any ban or physical restriction on meetings, gatherings or demonstrations affecting Taksim and Kizilay Squares, and all other squares and public areas, as well as restrictions on the right to free speech, be lifted

- all those responsible for commanding, enforcing and perpetrating the repression of the democratic rights of the people to demonstrate, starting with those who stood up to the destruction of Taksim Gezi Park, and the violent crackdown that resulted in the injury of thousands and five deaths, must be unseated and brought to justice, starting with the governors and police chiefs of İstanbul, Ankara, Hatay and Adana

- the use of agents such as tear gas must be prohibited

- those who were taken into custody due to their participation in the protests across the country must immediately be released and an official statement must be made to state that they will not be charged

- parks where we gather in moments of disaster must be opened to the public immediately, starting with Gezi Park (Taksim Solidarity, 2013).

During the occupation of Taksim Square and Gezi Park, community life was formed. Under the guidance of Taksim Solidarity, a communal kitchen, a Revolution Market, a Revolution Library, a children's playground and a medical clinic were built up. All these services were carried out voluntarily and nothing was for sale. Lists of necessities were declared via social media, and posters who wanted to contribute to the struggle could buy these necessities and leave them with the volunteers. Direct democracy was practised via forums, and all political currents and movements could express themselves by opening their tents and sharing documents. There was also a concert platform in which artists could perform plays. All the entrances to Taksim Square were closed by numerous barricades, with people able to enter the Square by crossing them, which were guarded 24 hours a day by young people from behind the barricades. This was a genuine alternative to the existing system (Erdemol, 2013: 21).

On the morning of 11 June, police entered Taksim Square, seeking to open the Square to traffic and to clean and protect the historical statue and the Atatürk Cultural Centre, which had been turned into a demonstration area for various political movements which had hanged their placards there. There was a low-level resistance against the police, with a very small group reacting against the police with Molotov Cocktails and which were then accused of being police agents by the Gezi Park protestors, who circulated photos of these 'resistors', showing them in police uniforms on other occasions. The Mayor of Istanbul stated that there would not be any similar intervention in Gezi Park; that they just wanted to open the Square to people and remove the barricades. Police forces were able to enter Taksim Square eleven days after the initiation of the movement, but only occupied a certain corner of the Square without confronting the demonstrators. That night, while the police were gathered around the famous statue, people carried a piano to the front of the police barricades and Davide Martello, a German pianist, gave a concert to the thousands of people sitting around him; and 
people sang songs, danced, chanted slogans, protested at the police violence and commemorated their young comrades who had lost their lives during the resistance. ${ }^{2}$

Four days later, on 15 June, police once again attacked Gezi Park, recapturing it from the peaceful demonstrators and putting an end to the 'Taksim Commune'. The Mayor and the government promised that Gezi Park would be preserved; the project for building a shopping mall would be delayed or cancelled (in some statements, it is delayed; in others cancelled) and the Mayor closed down the Park to people by showing reasons for the renovation of the Park. The Park was re-opened on 8 July (Amnesty, 2013).

The Taksim Commune lasted for fifteen days, something which was experienced for the first time in Turkish political history. This was the most significant demonstration of direct democracy, in which various and even opposing political currents and people acted in a democratic way and did not allow any provocative conflict between each other. After the invasion by the police, Taksim Solidarity stated that it continued to insist on its demands; that the struggle would continue; and that people would continue gathering in similar forums in all the public parks of their districts to continue the spirit of this communal, democratic experience (Taksim Solidarity, 2013; Yaraşır, 2013).

The clashes around Taksim continued for a few more days after the re-occupation of Gezi Park by the police. On 17 June, to protest at police force violence against all people coming together, one man, Erdem Gündüz, started an original protest in Taksim Square as a standing man; one man standing alone, without speaking or moving. This, perhaps the most passive of protests, created confusion among police forces as to what to do; they understand that he was protesting against them, so they should disperse him even though he did not move or chant slogans. This confusion and panic among the police motivated people to gather and protest at the government, giving the message that, if the police attacked everyone that moved, they would protest by neither saying anything or moving (CNNTürk, 18 June 2013).

\section{Resistance in other cities}

The June uprising spontaneously spread to other cities in Turkey. In eighty of a total of 81 cities - every one with the exception of Bayburt - people joined in with the antigovernment protests (Star, 20 September 2013). The police violence of 31 May was also protested at in many other cities on 1 June, with the mobilisation continuing throughout the month.

In Turkish metropolitan cities (which could be defined as those regional cities with universities, industrial zones and commercial centres, such as Ankara, Izmir, Adana, Hatay and Eskişehir), hundreds of thousands of people protested at the government and resisted police violence. After gathering in their own various districts, people walked spontaneously to the main city square and, when the police used violence, they formed barricades and resisted. The intensity of the violence was even greater in these cities.

2 The concert may be heard at: http://webtv.hurriyet.com.tr/20/50759/0/1/taksim-meydani-ndapiyano-dinletisi.aspx. 
According to the official reports of the Ministry of the Interior, on 23 June, some $2.5 \mathrm{~m}$ people joined anti-government protests in 79 cities. By 20 September, this number had increased to 3545000 in eighty cities (Star, 20 September 2013; Milliyet, 23 June 2013). These numbers are found controversial by many observers because, in the first days in Istanbul, Taksim Square, Istiklal Street and Gezi Park were full of people and there were massive demonstrations in all parts of Istanbul. Similarly, hundreds of thousands were on the streets in Izmir and Ankara; tens of thousands were at the demonstrations in Hatay, Eskişehir, Antalya, Edirne and Bursa; and there were many marches in almost all cities and towns. These protests continued non-stop for almost one month and major meetings and concerts were organised in the following months, gathering together hundreds of thousands of people.

Even if we simply accept the Ministry's official numbers, these statistics demonstrate that this uprising was the most massive mobilisation of people in the whole history of the Turkish Republic since 1923, or even in the entire history of modern Turkey since the $19^{\text {th }}$ century.

According to a report prepared by the authorities but not released officially, in the first 22 days of the protests, over $7.5 \mathrm{~m}$ people joined the protests. On 1 June, there were five hundred thousand people in Taksim and, on 2 June, this number increased to nine hundred thousand, with the total number that had poured on to the streets in all parts of Istanbul being three million people (Aydınlık, 13 September 2013).

\section{Casualties}

In Ankara, a policeman shot Ethem Sarıülük, a 27-year-old metal worker, just two metres away from his head, on 1 June and he died on 14 June in hospital. This moment was broadcast on TV channels.

In Eskişehir, Ali İsmail Korkmaz, a 19-year-old university student, was beaten up by a group of policemen and civil fascists on 2 June, and he died on 10 June without emerging from a coma.

In Hatay, a city on the Syrian border where people were suffering from the civil war in Syria, Abdullah Cömert, a 22-year-old worker, was killed by a gas capsule on 3 June.

In Istanbul, Mehmet Ayvalitaş, a 21-year-old worker, died on 2 July when a car hit him during the demonstrations.

Once more in Hatay, Ahmet Atakan, a 22-year-old worker, died on 10 September as a result of police violence.

Also, Mustafa Sarı (27), a police officer in Adana, fell from a bridge and lost his life while he was chasing protestors.

It has also been claimed (in Hürriyet) that police forces were forced to work long hours in order to suppress the protests.

According to a report from the Turkish Medical Association (TTB), in the first 45 days of the struggle, more than 10000 people reported injuries with 63 of them being serious. Eleven people lost eyes and 106 had serious head injuries (head traumas) due to pepper spray capsules being directed at them. It is estimated that the real number is 
far greater because of people's fear of going to hospital so as to avoid being recognised by the police.

Berkin Elvan (16) was shot with a pepper spray capsule in Istanbul while he was leaving his home for the grocery shop; he was still in a coma when this article was written (22 October 2013).

Zeynep Eryaşar (55) and Serdar Kadakal (35), in Istanbul, and İrfan Tuna (47), in Ankara, died as a result of heart attacks after being exposed to pepper spray, which is defined as a chemical weapon (TTB, 2013).

In addition, the Ministry stated that, as far as 20 September, 5341 people had been detained by the police forces and 160 people had been arrested. In the events up to 23 June, 240 police vehicles had been damaged and the total damage was put at 140 million Turkish Lira (€52m) (Star, 20 September 2013; Milliyet, 23 June 2013).

\section{The reasons for the uprising}

Millions of people and various political groups joined this mobilisation with different aims and reasons; therefore, it is difficult to show a few certain reasons for this uprising. The concrete and common demands of the movement with regard to Gezi Park were outlined above, as stated by Taksim Solidarity Platform, and focusing only on these demands would not provide us with a sufficient answer for the explosion of people's anger and their mobilisation in their millions in all parts of the country.

The main motivation for people was their anti-government opinions and feelings, which can be counted in a long list. The scope of slogans and demands of people changed from preserving Gezi Park to the resignation of the government, but the main demand could be defined as the latter; the government has been becoming increasingly authoritarian subsequent to a series of successful election results.

In order to understand the specific, concrete and daily reasons for the uprising, it would be better to understand the general perspective which paved the way to it.

The coup d'état and the military government, formed on 12 September 1980, acted very hard at the suppression of all left-wing activity in the country, which had reached its peak strength in the 1970s. All organisations were banned; thousands of people were arrested and tens of thousands were detained. A new system was formed in all aspects, spanning from the political system to the education system and the employment regime, in order to ensure that organisation and unionisation were made extremely difficult. The military regime also shifted from a welfare state to neo-liberal reforms and introduced a new economic system which was extremely pro-business and against labour rights.

By 1980, therefore, Turkey had joined the general global tendency of a shift to neoliberalism and the opening of its domestic market. After a near-forty year-long period of neo-liberal reforms, including privatisation; alterations to the employment regime via the introduction of more flexible work relationships; the expansion of precarious working conditions; the increasing dominance of transnational corporations over the national economy; and the continuous oppression of labour/people movements, it is possible to establish a link between the current uprising in Turkey with social movements at the global level (Yaraşır, 2013). The role of the middle classes and white- 
collar employees in the June uprising is widely debated, and we focus on this in the following sections, but it is necessary to mention that those educated employees who participated in the movement at a broad level are the ones who have been affected negatively by these neo-liberal economic policies, losing their previous privileges and getting closer to a blue-collar working class.

After elected governments had internalised the logic of the coup d'état, they preserved the main characteristics and parameters of the system. However, the 1990s were marked by turmoil in which, on the one hand, civil war with the Kurdish separatist nationalist movement intensified; while, on the other, successive economic crises during the decade until 2001, as well as an insistence on privatisation and neo-liberal reform, worsened the economic situation. At the same time, coalition governments and political factions within the ruling elite were making it more difficult to sustain a stable, well-functioning political system.

In 2001, Turkey faced a major economic crisis that caused the three parties in the coalition government to lose their representation in the parliament following the election by not being able to overcome the ten per cent threshold and in which two of them (DSP and ANAP) were completely eliminated, losing their credibility in society. After the crisis, the International Monetary Fund formulated a programme whose prerequisites were more privatisation and more precarious working conditions, together with more strict control of the financial and banking system.

Additionally, the result of the imprisonment of PKK leader Öcalan in 1999 was that, by 2001, there was relative peace and a very much lower level of armed conflict in the context of the Kurdish question.

AKP (the Justice and Development Party) was formed in August 2001 by cadres of the former Islamist party (Fazilet Partisi), which had been banned by the Constitutional Court. The founders claimed that they had changed politically and had accepted conservative democracy with a moderate Islamic ideology. Enjoying huge support from the US and the EU, as well as the media, they were able to form a government in November 2002 while the rest of the traditional parties were suffering a legitimacy problem in the eyes of the people due to the severe economic crisis.

AKP strictly maintained the IMF programme of the previous government, enjoyed the opportunity of relative peace in the Kurdish issue and demonstrated itself as a reformist party against the so-called 'forces of the status quo', which were defined as the traditional Kemalist bureaucracy of military, judiciary and civil organisations that had been against the AKP government from day one because of its Islamist roots. This 'reformism' was supported by the US and the EU because a faction of the ruling elite held an attitude of suspicion both towards the US, because of its middle east policies (the Turkish military's objection to the US-led Iraq invasion was criticised by US officials), and towards the EU, because of its support for an Islamist government. AKP also found favourable international economic conditions in which foreign capital and short-term debts could be directed to the Turkish economy, which provided high interest rates for 'foreign investors'.

Therefore, in the first five years of the AKP government, everything seemed to go well: it was able to enjoy support from the US and the EU; it could receive foreign capital-debt easily; it could implement the IMF's economic package that would show 
the economy was being restored and going well, with high economic growth rates; and the Kurdish issue was proceeding in a relatively peaceful manner in comparison to the violent decade of the 1990s. The AKP was acting as a reformist democratic party, gaining support from liberal intellectuals of both left and right, together with media and business groups. Meanwhile, through 'show trials' against cadres of the Kemalist bureaucracy in the military, judicial and executive organs of the state, by claiming that they were organising a plot and a coup d'état against the elected government, it was able to strengthen its position in the transformation of the state vis-à-vis the rival political elite. AKP also succeeded in privatising all state-owned enterprises and distributing state-owned estates to profit-seeking business groups, and also took important steps in transforming workplace regimes by the introduction of more precarious working conditions (Sönmez, 23 June 2013).

However, the picture began to change in the second half of the eleven-year rule of the AKP government. AKP was able to succeed in all elections during its rule and to strengthen its share of the vote, which gave more confidence to the government such that it began to claim that it represented 'the will of the nation'. This feeling of power amidst a weakening of the bureaucratic opposition provided a more arrogant way of conducting politics, refusing the demands of the opposition, transforming state mechanisms in a more open and challenging way and leaving behind the image of reformism. AKP began to act in a more authoritarian way, aiming to legitimise its decisions with Islamic ideological references, quitting its alliance with liberal intellectuals and fostering neo-liberal policies (Erdemol, 2013: 9).

Economic conditions began to deteriorate due to the global economic and financial crisis, with lower growth rates and the repayment of debt giving danger signals, alongside greater unemployment and poorer working conditions that threatened the working classes. Similar problems occurred with respect to the Kurdish issue, with the Kurdish movement being dissatisfied with the AKP because of the gap between promises and practices, while the armed conflict began once again. This led to the acceptance of the government of negotiations and bargaining in secret with the imprisoned PKK leader, Öcalan, causing suspicion and anger both in the Kurdish movement and in the left- and right-wing Turkish nationalist-Kemalist movement. This 'peace process' and the ceasefire created favourable conditions for people to mobilise (Müftüoğlu, 16 June 2013; Yaraşır, 2013; Kocadağ, 2013: 8).

Additionally, the 'show trials' against the military and civil Kemalist bureaucracy began to be exposed as a result of controversies and unlawful, fake evidence, while society's support for these trials began to decrease. The AKP government's Islamist projects and its intention to change the education system according to Islamic ideology, as well as its arrogant way of implementing such changes without a recognition of any need to consult, resulted in angering the secular masses. Last but not least, international support for the AKP began to be questioned. Turkey's 'active' middle east policies its open support for the Muslim Brotherhood and its intervention in the domestic politics of Arab countries and logistical support for the al-Qaeda militants in the Syrian civil war - began to be criticised by the Obama administration, while the EU became more suspicious of the AKP's rule (EC Progress Report, 2013; Sönmez, 29 July 2013). 
Furthermore, AKP began to use more police violence towards its opponents. Just focusing on a few months before the June resistance, it is possible to see police violence towards trade unions and workers seeking to celebrate May Day in Taksim Square; while during April, police continuously attacked those protestors, including famous Turkish actors and even Costa Gavras, with pepper spray and water cannon who were protesting at the demolition of the historic first cinema in Turkey, Emek Sinemas1, and constructing a shopping mall in its place. Police violence was also used against many different protesters, from feminist organisations to youth movements and football fans/ ultras, that it was widely said by opposition figures that all members of the opposition would taste pepper spray at least once in their lives.

PM Erdoğan's speeches and his arrogant style also motivated people to mobilise against him. Almost every day, his speeches on different occasions and at various meetings, all of which were broadcast live across all TV channels, also resulted in reaction from citizens and caused anger and opposition towards Erdoğan's rule (Erdemol, 2013: 16). In particular, we might cite:

- his comments about secular lifestyles, criticising young lovers kissing each other and walking hand-in-hand in public spaces

- his insistence on advising couples to have at least three children

- his comments on the abolition of abortion

- his definition of all those consuming alcohol as alcoholics, telling them to drink in their homes and his instruction to the local municipality of Beyoğlu (including Taksim) not to let bars and cafes have tables outside on the street; as well as his explanation of the recent law restricting the sale of alcohol in terms of Islamic references, with his answer to opposition critics that he would carry out God's commands instead of laws written by two alcoholics, referring to the founder of the modern Turkish Republic, Mustafa Kemal Atatürk, and his comrade, the 2nd President following Atatürk, Ismet İnönü

- his insistence on building two mosques at Taksim Square and Camlica, which would serve as the ideological symbols of the 'new regime' or 'the New Turkey'

- his instruction to media business leaders to dismiss well-known authors and columnists who criticised the government and to create a media that supported the government.

There is clearly a long list of reasons. In short, PM Erdoğan's arrogant style of speech; the economic problems; the developments in the Kurdish issue (the Kurdish movement is not satisfied with the so-called 'peace process' while the Kemalist-Nationalist movement increasingly opposes it from a fear of separation); police violence against all opposition forces; people's feelings of threat towards secular lifestyles and freedoms; and the weakness of conventional opposition parties - all these have created favourable conditions in which people have sought to mobilise.

\section{The government's reaction}

The AKP government was shocked at this sudden and massive, militant uprising against its rule. The government reacted with excessive police violence on protestors, referred to above, with thousands of people being injured and several deaths. The right to peaceful demonstration, which is a constitutional right, was violated by police forces 
not only in June during the days of the uprising but this violence continued in September and October, mainly in Istanbul (in Kadıköy and Taksim), as well as in Hatay and in Ankara (ODTÜ). Even the President of the Union of Turkish Bar Associations, Metin Feyzioglu, stated that they only demanded the recognition of their right to criticise the PM and that the opposition should not be treated as an enemy (Feyzioğlu, 2 September 2013).

On the third day of the uprising, 2 June, PM Erdoğan left the country for a tour of north Africa, returning on 6 June. PM Erdoğan was thus not around in the first week of the uprising, leaving his ministers and the president to try to deal with the issue. Before leaving the country, he stated that all those participating in the uprising were çapulcu, which means 'looters' in English. This accusation was taken on by millions of people, while the protestors began to define themselves as çapulcu, even transferring this word to English in the forms of chapuller and chapulling. ${ }^{3}$ He also stated that he represented the will of the nation, having received $50 \%$ of votes in the elections; and, instead of opposing him on the streets, PM Erdoğan invited his opponents to compete with him in the ballot booths. He also said that, if the opposition could mobilise one hundred thousand people, he could mobilise one million. He claimed that he was trying hard to convince the $50 \%$ to stay in their homes rather than go out on the streets to attack the protestors-chapullers, giving signals of a civil war (Hürriyet, 4 June 2013).

Providing a few more statements of the government would be sufficient to demonstrate its logic. On 2 June, PM Erdoğan stated:

We cannot sit and watch a few hooligans coming to the Square to provoke people. Because when the nation voted for us, they voted for us to guard our history.

On 24th June, PM Erdoğan stated:

They were still all there. The limits of tolerance have been exceeded. I told my Minister of the Interior: within 24 hours, you will clean up the Atatürk Cultural Centre. You will clean up the Square. You will clean up the statue. After that, you will clean up Gezi Park. They ask: who gave the order to the police? I did. I did. Yes. Were we supposed to sit and watch the forces of occupation? Were we supposed to wait until the whole world would join in and celebrate?

Additionally, Egemen Bağış, Minister for EU Negotiations, stated on 15 June:

I am specially calling all our citizens who have been giving support to these protests. They should return to their homes. Unfortunately, at this stage, the state will have to consider every individual there as members of terrorist organizations. (Amnesty, 2013)

PM Erdoğan's strategy sought to polarise society in order to keep his supporters behind the government and to preserve the unification of the party. He constantly referred to protestors as 'they' and created a division between 'them and us'. Before the June uprising, PM Erdoğan had been providing statements that he was the PM of all the nation and the PM of all the citizens, without making any difference between those

3 http://en.wikipedia.org/wiki/Chapulling. 
who voted for him and those who had not, but, after the uprising, he began to calculate his support as $50 \%$, aiming to show that voting preferences may not be changed and he that he was acting as PM of this $50 \%$ with the 'they' and the 'others' being out of scope; that there was no need to convince 'them'.

We showed above that the AKP was able to get higher votes after a successful fiveyear term, both as a result of the economic position and as a result of the peaceful process with regard to the Kurdish issue, benefiting from a period of stability after the political turmoil of the $1990 \mathrm{~s}$, as well as by effective use of the media and the elimination of the bureaucratic power of the opposition via 'show trials'. However, the AKP is a kind of coalition party, constituted from a range from Islamists to right-wing liberals, and it has only been able to succeed by taking the votes of the centre-right and adding these to its Islamist core. Therefore, a successful opposition movement may be able to attract centre-right votes, which may be defined as conservative and secular, and there may thus be a danger of division within the party. However, it could be seen by October that, despite continuing talk on the preparation of a new right-wing bloc within AKP (Aydınlık, 10 March 2013), PM Erdoğan has been successful in keeping the party together and polarising the nation into two main groups: $50 \%$ vs. $50 \%$.

In order to polarise society, PM Erdoğan constantly repeated some claims against the protestors, such as that 'They drank alcohol inside a mosque;' 'They attacked a young lady because she was wearing headscarf,' which may have provoked the religious beliefs and sensitiveness of conservative people. However, these accusations could not be proved and the conservative masses did not prefer to mobilise, despite the PM's special attempts (Kocadağ, 2013: 12). PM Erdoğan even targeted and threatened the richest business group, Koç Holdings, claiming that they were supporting the resistance. The 'evidence' for this was that, after the police violence, protestors were able to save themselves by hiding in the Divan Hotel, owned by Koç Holdings (Sönmez, 27 July 2013).

The June uprising also exposed the existence of political power-media relationships, with mainstream TV channels not giving news of the uprising in Turkey because of the intense pressure of censorship coming from the government. During the most intense clashes in Istanbul, Ankara and other cities, and while hundreds of thousands of people were marching, CNNTürk was broadcasting a documentary of penguins while NTV, another main news channel, was showing a gourmet programme. People protested against these news channels, burning a vehicle owned by NTV, while penguins became another symbol of the movement.

The advisers of the PM and some pro-government columnists also began a campaign against the chapullers, fabricating many theories to denigrate the movement. The common theory was that the uprising was planned and co-ordinated by foreign forces which were against the growth of power of the Turkish Republic, which was shifting from being a regional power to a global player, and in a possession of a stable and strong economy. Then, who are these foreign forces? It is not possible for these theorists to target the US or the EU, so they targeted different forces. PM Erdoğan also accepted some of them, talking about 'interest rate lobbies'. Most probably, the 'interest rate lobby' was defined as those financial speculative market players whom the Turkish government had worked so hard to attract in respect of short-term debts. Then, PM 
Erdoğan also talked about the role of the Jewish lobby, which was hardly criticised by the US or Israel, before dropping this group from the discourse. Additionally, some advisors of Erdoğan showed Otpor, Soros and other networks as ones who wanted to create trouble within Turkey (Ergin, 30 August 2013; Hürriyet, 10 June 2013; Yeni Şafak, 15 June 2013; ODA TV, 16 June 2013).

However, the government refused to accept this uprising as a democratic and national movement, bringing together various political currents and ordinary citizens who had concerns about the future of the country. Despite such statements, President Abdullah Gül gave a positive view in meetings with US and EU officials and in interviews with the international media. For instance, President Gül stated on 24 September in the USA that he was honoured with the Gezi movement that showed the high level of democratic progress in Turkey that Turkish citizens shared similar demands as the citizens of the US or the UK; however, he did claim that, after a few days, this mobilisation had begun to be exploited by radical currents (Hürriyet, 24 September 2013).

\section{Who are the chapullers?}

There have been many debates on who the chapullers are. Is this a revolt of whitecollar workers, the middle classes or Generation Y? Is this an uprising for liberties and freedoms, or is this a part of the class movement, or is it a revolt of conscience? It is not possible to point to a certain stratum of society in this movement as responsible for the uprising in which millions participated; therefore, in order to understand who are the chapullers, we must firstly focus on the core of the movement - i.e. those staying in Gezi Park and creating the Taksim Commune - and then we may develop a broader view from which to understand the social classes and sections of society which participated at a massive level.

The people who stayed in the Park in their tents were mostly young people, university students and young professionals. Just focusing on the Gezi Park people would not provide us with the general picture, but this was the core group that motivated the struggle. There are three main research studies on the people in Gezi Park.

The first was carried out by Bilgi University on 4 June, just a few day after the occupation of the Square with three thousand protesters, and conducted in twenty hours via the internet. According to this research study:

- $64 \%$ were between 19 and 30 years old

- $53.7 \%$ had not previously participated in such demonstrations, so this was their first experience. Seventy per cent did not feel close to any political party

- the authoritarian rule of PM Erdoğan is the primary reason for being in Gezi Park, mentioned by $92.4 \%$. The excessive violence of the police is the second reason, mentioned by $91.3 \%$, and the violation of democratic rights by $91.1 \%$. People participating to save the Park stood at $56.2 \%$

- $81.2 \%$ stated that they were struggling for freedoms and $64.5 \%$ for a secular system

- $79.5 \%$ were against a coup d'état (T24, 4 June 2013).

The second research study was carried out by Konda Research Company on 6-7 June, with the participation of 4441 people staying in different parts of the Park (different political groups had tents in different parts of the Park) over a thirty-hour period: 
- $69 \%$ had heard about the movement by social media and $15 \%$ from their friends

- $73 \%$ decided to come Gezi Park after the police violence

- $30 \%$ were staying permanently in the Park; the rest visited it every day or had done so on a few days over the week

- $6.4 \%$ came to the Park in support of the party to which they were affiliated; $92 \%$ of students decided individually to come to the Park

- $58 \%$ were there because of the feeling that their freedoms were in danger. Thirty seven per cent were against the AKP and $34 \%$ wanted greater freedom

- $52 \%$ were not decided on the party for which they would vote or otherwise would not go to the ballot box

- in the previous elections, $41 \%$ had voted for CHP; $17 \%$ were under 18 years old; $20 \%$ did not vote; $15 \%$ voted for independent candidates (the Kurdish nationalist party and some socialist and nationalist parties participated in the elections with independent candidates to overcome the $10 \%$ threshold)

- in the next elections, $31 \%$ would vote for the CHP; $8 \%$ for the BDP (Kurdish Nationalist Party-Peace and Democracy Party); $18 \%$ would not vote for any party; and $29 \%$ were as yet undecided

- the average age was 28 and $50.2 \%$ were women

- $13 \%$ were MA or PhD students; while $43 \%$ had an undergraduate diploma

- $52 \%$ were wage-earners while $37 \%$ were students (Konda, June 2013).

The third research study was conducted by the GENAR Research Company on 8-9 June with 498 people, $78 \%$ of whom were people in Gezi Park with the remainder drawn from people in and around Taksim Square:

- $58 \%$ stated that the real reason was the personal characteristics of PM Erdoğan, while $46 \%$ had joined in order to support and contribute to the resistance

- when asked about the major problems of Turkey, $19 \%$ of protestors thought that this was the absence of freedom; $16 \%$ injustice, inequality and discrimination; $11 \%$ unemployment; and $10 \%$ the economy

- thirty three per cent defined themselves as Kemalist; $19 \%$ as pro-freedom; $12 \%$ as socialist; $9 \%$ social democrat; and $8.4 \%$ democrat

- similar to the Konda research, in this research study $54 \%$ said they were wageearners (GENAR, June 2013).

In a further piece of research carried out by the Konsensus Research Company, conducted between 3 and 19 June in 81 cities of Turkey among 1500 people, $54 \%$ of society supported the Gezi Park mobilisation, while $29 \%$ of those who had voted for the AKP also supported the Gezi Park movement (Konsensus, June 2013).

In a broader sense, it is possible to count the social classes and sections of society that supported the June uprising as follows.

Wage-earners joined the movement on a massive scale. The traditional working class was at the mobilisation. However, trade unions did not have any effect on the movement. Moreover, two of the three confederations, namely Türk İş and Hak İş, which have pro-government leaderships, signed a common declaration, together with some employer associations, against the movement. Nevertheless, some progressive unions within Türk İş supported the movement. DISK (the Confederation of Progressive Trade Unions of Turkey) and KESK actively supported the uprising and, by being 
a member of Taksim Solidarity Platform, they called on their members to join the movement. They also declared a general strike on 5 June and organised demonstrations under their own banners (NTVMSNBC, 5 June 2013). However, these unions are relatively weak organisations (DİSK has 100000 members set against sixteen million wage earners) and these strikes had symbolic importance. Workers participated in the struggle after work hours, but they did not stop production. Nevertheless, wage-earners - blue- and white-collar workers, sub-contracted workers and workers in precarious working conditions - did join the resistance on a massive scale (Boratav, 22 June 2013). Due to the weakness of labour's class organisations, it is not possible to count the rate of participation of the working class, but this may be seen in terms of the high levels of mobilisation in those districts in which the working-labouring classes reside in Istanbul, Ankara, Hatay, İzmir, Eskişehir and other cities (Korkmaz, 19 August 2013).

White-collar workers, 'plaza workers' (those working in skyscrapers for big capital), and highly-educated employees were all active during the mobilisation. The high level of participation and activism of these employees was surprising because of their low levels of organisation and the relatively high wages that they earn; however, it was precarious working conditions and the demands for freedoms and liberties which motivated these sections of society, which are also ones facing rapid proletarianisation (Bürkev, 24 June 2013; Boratav, 22 June 2013; Yıldızoğlu, 27 June 2013). They were also able to use social media very effectively. On 3 June, thousands of 'plaza workers' protested at the NTV media channel in their lunch break in the richest district of Istanbul on account of the censorship of the uprising (Bianet, 3 June 2013).

Women were very active in the movement. Women were feeling threatened concerning their lifestyles, and the feminist movement had been active before the uprising in protesting against the government and the Prime Minister when they made statements about the ban on abortion and having at least three children; the introduction of flexible working conditions for women; and the various statements of the Prime Minister and other ministers about dresses and moral principles for women. Therefore, the accumulation of such concerns motivated women to join the resistance on a massive scale and in an active and militant way.

Young people were also very active during the mobilisation. By using social media effectively and presenting their own style of humour and slogans, they were able to mobilise in a speedy and massive way, and they were also able to resist behind the barricades both day and night.

Additionally, groups of football fans were very active in the movement. Turkish football has become highly politicised during the period of AKP government. The government has tried to control and influence football teams and, when they were unsuccessful in their attempts, 'show trials' were introduced once again by claims of chicanery by the only ones who had refused the government's demands, such as Fenerbahçe and Beşiktaş. During these trials, groups of fans mobilised to defend their teams, clashing with the police on many occasions. This process politicised the fans and many left-wing fan groups were formed. During the uprising, these groups mobilised with high levels of motivation, and they were able to transfer their experiences in clashes with the police and the formation of barricades to other people. In particular, fans of Beşiktaş, Fenerbahçe and Galatasaray, which had serious conflicts with each other 
before the uprising, resisted side-by-side and 'Istanbul United' and the 'Brotherhood of Colours' became their slogans. Çarşı, the Beşiktaş fan club and one of the oldest football fan groups in Turkey since the 1980s, well-known for its left-wing and social political thought, became the 'star' of the resistance, using creativity in the struggle against the police. Beşiktaş is the closest district to Taksim Square and the toughest confrontations took place in Beşiktaş; therefore, the fans of the football club of this district were active during the resistance and Çarşı attracted much sympathy from people.

Alevis ${ }^{4}$ also joined the resistance on a massive scale. Alevis have strongly positioned themselves against the AKP Government, which has followed a Sunni Islamist politics. The AKP government has sought on several occasions to initiate a reform package for Alevis, but these have all failed. Alevis face discrimination, especially in the state bureaucracy; their place of worship, Cemevi, is not recognised by the state; Alevi children are forced to learn Sunni Islam in primary schools; and the government transfers large amounts of money to the Directorate of Religious Affairs which only supports Sunni Islam. Alevis campaign to be recognised by the state and defend their practices and policies against charges of being contrary to the secularity of the state.

Kurds also joined the resistance, although the Kurdish national movement, with its legal and illegal-armed organisations, held a suspicious approach towards the uprising. The AKP government, as we have seen, has initiated a peace process to resolve the Kurdish question, including negotiations in secret with PKK leader Öcalan, who is in prison, and with the pro-Kurdish BDP (Peace and Democracy Party) in parliament. The AKP government has offered and promised reforms in pursuit of the Kurdish question, while the PKK has declared an armistice and called on their armed groups to leave the country for their liberated zone in northern Iraq. When people mobilised spontaneously in June, most of them were carrying the Turkish flag, which is defined as a sign of patriotism for people, and the Kurdish movement had concerns in understanding the political essence of the movement, which might have been a right wing-nationalist uprising. However, the leaders of the Kurdish movement later criticised their position when it was clearly understood that this uprising took a politically left-wing stance. With the AKP not being able to satisfy the Kurdish national movement with its approach, they declared that they would support the resistance but, in practice, the Kurdish movement's organised forces did not mobilise their masses and there were not major demonstrations in Kurdish cities.

We should note that one of the first symbols in the peaceful resistance to preserve Gezi Park was S. Süreyya Önder, a well-known film director and BDP member of parliament, who was part of the movement to prevent the municipality's bulldozers from destroying Gezi Park on 29 and 30 May.

There were some attempts in the mainstream media to define the chapullers as being people without ideologies. However, the chapullers had clear demands. They wanted

4 Alevite society is a minority religious group in Turkey. Separate from the Sunni Muslim majority, Alevite belief is in line with Shia Muslim but originates in Anatolia and is influenced by former Anatolian and pre-Islamic Turkish religions and beliefs. Alevis are secular and the majority tend towards left-wing views. 
the resignation of the government. They want to save the environment and object to neo-liberal rent-seeking urbanisation projects. They are against all kinds of discrimination against women, LGBTT, Kurds and Alevis. They are against authoritarian rule and want more freedom. These are naturally 'left-wing' demands and clearly own an ideology (Erdemol, 2013: 14).

\section{Conclusion: from June to November}

When Gezi Park was re-occupied by police forces, Taksim Solidarity Platform called on people to gather in public parks in their districts, organise discussion forums, mobilise and continue the resistance. In all parts of Istanbul and in many cities and towns, people began to gather each night in public parks and practise direct democracy, and debate, decide and act together. In July and August, people gathered to protest at the government on certain days, and the protests and clashes continued in Istanbul, Ankara, Eskişehir and Hatay.

Both from the resistance and the government, there was talk of a 'return of the uprising in September', because people were on holiday and, in September, people would return their homes, universities would re-open and the football league would start. In short, the resistance would then continue.

The government prepared for a possible 'hot September' scenario by buying more stocks of pepper spray and police vehicles. Furthermore, the Prime Minister and ministers warned people against continuing the resistance. For instance, the Minister of Sport and Young People and the Minister of the Interior stated that they would not let protests take place in football stadiums. Special prosecutors would be employed in stadia, there would be electronic tickets and cameras everywhere that would make it possible for the police to watch everyone in the crowd and, if there was an attempt at a protest, police and the prosecutors would intervene and prevent these people from coming to the stadium again (Radikal, 31 July 2013). Additionally, the state department of dormitories and scholarships stated that there would not be scholarships or places in dormitories for students who had joined the protests (Bugün, 31 July 2013). The Mayor of Istanbul banned all events and demonstrations in Gezi Park after its re-opening. Even a couple who met during the resistance and wanted to merry at Gezi Park were banned from doing so and the police attacked people who had gathered for their wedding with pepper spray (Milliyet, 20 July 2013).

The government's policy was to suppress all opposition and protests in July, August, September and October by the use of police violence and to hinder the opposition from becoming organised and strengthening. The increase in violence was intended to divide and weaken the opposition and the resistance. However, from September to November, in Istanbul (Kadıköy and Taksim) and in Ankara (at the Middle East Technical University), there were mobilisations of people and the police used violence against them. People did not mobilise at a similar level of the June uprising, but preferred to gather in forums, organise large concerts and make peaceful demonstrations. In short, the opposition/resistance preferred to follow its own path and did not accept the government's choice of the orchestration of more violence.

In the universities, the threat to cut scholarships did not work and university students in many universities have continued their protests against the government. The gov- 
ernment has focused on METU (one of the most distinguished universities in Turkey), initiating in October a project to destroy the METU forest and build a motorway, at which all universities have protested, with many clashes with police forces.

In football stadia, tens of thousands of people have been protesting at the government and at police violence in the $34^{\text {th }}$ minute of matches, this being the traffic code number of Istanbul. The threats against football fans have not worked.

To conclude, the resistance-opposition movement has gained a moral superiority over the government since the June uprising. Before June, the AKP government was seen as unchallengeable and enjoyed the moral high ground with regard to its opponents but, since June, the AKP government has been in a defensive position. The support it has from both domestic and international politics is on the decrease. Erdoğan is perceived as an authoritarian ruler and his opponents refer to him as a 'dictator'. Additionally, Erdoğan has rapidly lost his charisma and support in the middle east. Last, but not least, the economic situation is sounding a note of alarm, with economic growth based on foreign debt creating danger signs concerning the country's stability.

Turkey has three elections in the coming months. The closest is the local elections in March 2014; then there will be presidential elections in the middle of 2014; and a general election in 2015 .

The local election is more than just a local election; it will reflect the current polarisation in society and especially the local elections in İstanbul, the most populous and most important city, will reflect the future of the AKP government.

The presidential elections will also be important, because the President has a more symbolic role and tends to be independent of daily politics and parties, with the Prime Minister being the main leader of the executive in the Turkish system. Therefore, if Erdoğan is elected President, he would not be able to control his party and the government. The main alternative to Erdoğan is the current President, Abdullah Gül, and it is well-known among the public that Mr. Gül and Mr. Erdoğan have had conflicts with each other. Even during the June uprising, Mr. Gül delivered positive statements about the protestors in Gezi Park and expressed condolences for those people who had lost their lives during the mobilisation (EC Progress Report, 2013). Before the June uprising, PM Erdoğan stated that he preferred a presidential system, as in the USA, and that he would like to change the system; however, given the June Uprising, this seems not to be possible as this is an argument which even PM Erdoğan does not prefer to repeat. Therefore, this election, which would be affected by the results of the local elections, will provide a clearer picture about the general election.

This was an uprising which targeted the government but which did not aim to overthrow it (Erdemol, 2013: 11). However, the uprising did open a new chapter in the ninety-year history of the Turkish Republic (Yaraşır, 2013). The June uprising clearly changed the political environment and the power balances of the political elite. Furthermore, this uprising has provided more fertile conditions for the out-of-parliament opposition and other social organisations. The June uprising showed that the AKP government is in decline and could not continue its power in the long-term, and it broke the chains of the left, which has been suppressed by the military junta in 1980, giving confidence once again to the movement. The June Uprising did not simply occur and 
finish. The new chapter that it has opened in the Turkish political system is something that will affect the whole future of Turkey.

\section{References}

Amnesty International (2013) Gezi Park Protests: Brutal Denial of the Right to Peaceful Assembly in Turkey October, London.

Aydınlık Gazetesi 10 March 2013 'AKP İçinde Yeni Parti Hazırlığı' http://www.aydi nlikgazete.com/mansetler/19877-akp-icinde-yeni-parhazirligi.html [last accessed on 20 October 2013].

Bianet 3 June 2013 'NTV önünde gezi park1 protestosu' http://www.bianet.org/bianet/ yasam/147168-ntv-onunde-gezi-parki-protestosu [last accessed 20 October 2012].

BBC Türkçe 6 June 2013 'Erdoğan Dönüyor' http://www.bbc.co.uk/turkce/haberler/ 2013/06/130606_erdogan_donuyor.shtml [last accessed 20 October 2013].

Boratav, Korkut Korkut Boratav'la Röportaj 22 June 2013 http://www.sendika.org/20 13/06/her-yer-taksim-her-yer-direnis-bu-isci-sinifinin-tarihsel-ozlemi-olan-sinirsi z-dolaysiz-demokrasi-cagrisidir-korkut-boratav/ [last accessed 20 October 2013].

Bugün Gazetesi 31 July 2013 'Eylemciye burs tartışması' http:/gundem.bugun.com.tr/ eylemciye-burs-tartismasi-haberi/741275 [last accessed 20 October 2013].

Bürkev, Yalçın Yalçın Bürkev’le Röportaj 24 June 2013, sendika.org.

CNNTürk 18 June 2013 'Taksim'de Duran Adam Eylemi' http://www.cnnturk.com/ 2013/turkiye/06/18/taksimde.duran.adam.eylemi/712011.0/ [last accessed 20 October 2013].

Erdemol, Mustafa K (2013) Gezi Parkı Direnişi, Küçük Bahçede Büyük Kıyamet Yazılama Yayınevi: İstanbul.

Ergin, Sedat 'Obama'dan Türkiye’ye Yeni Bakışın Şifreleri’ Hürriyet Gazetesi 30 August 2013.

European Commission (2013) Turkey 2013 Progress Report October.

Hürriyet Gazetesi 4 June 2013 'Başbakan: Yüzde 50’yi evinde zor tutuyorum' http:// www.hurriyet.com.tr/gundem/23429709.asp [last accessed 20 October 2013].

Hürriyet Gazetesi 10 June 2013 'Kimdir bu "faiz lobisi”' http://www.hurriyet.com.tr/ ekonomi/23472025.asp [last accessed 20 October 2013].

Hürriyet Gazetesi 24 September 2013 'Gül: Gezi Olayının Başlangııı ile Gurur Duydum' http://www.hurriyet.com.tr/gundem/24774561.asp [last accessed 20 October 2013].

Hürriyet Gazetesi 2 September 2013 'Metin Feyzioğlu'ndan Sert Eleştiriler' http:// www.hurriyet.com.tr/gundem/24633061.asp [last accessed 20 October 2013].

Kocadağ, Arif(2013) Taksim Meydan Okuması. İsyan Edin, Birleşin, Örgütlenin! July, Umut Yayımc1lik: İstanbul. 
Korkmaz, Eren “Gezi” Notları ve Beklentiler 19 August 2013 http://www.sendika.org/ 2013/08/gezi-notlari-ve-beklentiler-eren-korkmaz/ [last accessed 20 October 2013].

NTVMSNBC 7 April 2013 'Emek' Protestosuna Biber Gazı http://www.ntvmsnbc.co $\mathrm{m} / \mathrm{id} / 25434134 /$ [last accessed 20 October 2013].

NTVMSNBC 5 June 2013 Sendikalardan “gezi” grevi http://www.ntvmsnbc.com/id/ 25447157/ [last accessed 20 October 2013].

Milliyet Gazetesi 20 July 2013 'Gezi parkında “nikah” gerginliği!' http://gundem.milliyet.com.tr/gezi-parki-nda-nikah-gerginligi/gundem/detay/1739405/default.htm [last accessed 20 October 2013].

Müftüoğlu, Oğuzhan 'Gezi Eski Kalıpları Çöpe Attı’ Akşam Gazetesi 16 June 2013.

Radikal Gazetesi 31 July 2013 'Stadyumda 'her yer taksim her yer direniş” yasağı!' http://www.radikal.com.tr/spor/stadyumda her_yer_taksim_her_yer_direnis_as agi-1144238 [last accessed 20 October 2013].

ODA TV 16 June 2013 Gezi direnişinin ardında Otpor mu var? http://www.odatv.com/ n.php?n=gezi-direnisinin-arkasinda-otpor-mu-var-1606131200 [last accessed 20 October 2013].

Social Media and Political Participation Lab/New York University (2013) A

Breakout Role for Twitter? The Role of Social Media in the Turkish Protests http:// smapp.nyu.edu/reports/turkey_data_report.pdf June [last accessed 20 October 2013].

Sönmez, Mustafa 23 June 2013 Bir Meta Olarak İstanbul http://mustafasonmez.net/? $\mathrm{p}=3269$ [last accessed 20 October 2013].

Sönmez, Mustafa 27 July 2013 Fesuphanallah, Sıra \#direnKOÇ’ta http://mustafasonm ez.net/?p=3405 [last accessed 20 October 2013].

Sönmez, Mustafa 29 July 2013 AKP'nin D1ş Desteği Çökerken http://mustafasonmez . net $/ \mathrm{p}=3412$ [last accessed 20 October 2013].

Taksim Solidarity 22 June 2013 'To the Press and the Public' http://taksimdayanisma.org/basina-ve-kamuoyuna-22-haziran-2013?lang=en [last accessed 20 October 2013].

Türk Tabipler Birliği Gezi Direnişi Sürecinde http://www.ttb.org.tr/index.php/gezidir enisi.html [last accessed 20 October 2013].

Yaraşır, Volkan 'Gezi Parkı Direnişinden Ayaklanmaya' Kızılbayrak Gazetesi 3 July 2013.

Yeni Şafak Gazetesi 15 June 2013 'Kod adı İstanbul isyanı’ http://yenisafak.com.tr/ gundem-haber/kod-adi-istanbul-isyani-16.6.2013-533074 [last accessed 20 October 2013]. 
Y1ldızoğlu, Ergin Gezi Olayı"nın yarattığ1 yeni “zaman” üzerine düşünürken http://w ww.sendika.org/2013/06/gezi-olayinin-yarattigi-yeni-zaman-uzerine-dusunurkenergin-yildizoglu/ [last accessed 20 October 2013]. 